Prof. T. B. Wood described in detail experimental investigations from which he concludes that two factors are involved in the term strength, that of size, which is a function of the gas evolved by the flour due to its diastatic capacity, and that of shape, which is a function of the proportion of acid and salts present in the flour. $\mathrm{Mr}$. Julian Baker mentioned some determinations of the diastatic power of flours from which he infers that diastase is always present in excess, so that the determination of diastatic power will not be of much value in judging a flour. Dr. E. F. Armstrong alluded to the importance of the gas formed during the early stages of fermentation in distending and affecting the gluten, and pointed out, as also did Mr. Baker, that the enzymes of flour other than diastase should receive the closest attention.

\section{GEOLOGY AT THE BRITISH}

\section{ASSOCIATION}

THE papers on local geology which followed the presi1 dent's address yere of more than ordinary interest. Mr. Fox Strangw ds dealt wist the district round Leicester a a whole, dwellin specially on those points which are oscurg and reatre further elucidation. Prof. Watts gav an ackoy of his researches in the rocks of the Charnfood Forest. Dr. F. Bennett and Dr. B. Stacey, in describing the felsitic agglomerates occurring at Bardor Hill and in other parts of Charnwood, gave a new reding of some of the features described by Prof. Watts. These questions raised an interesting discussion, which was carried on, not only in the sectional meetings, but also in the field, when the localities were visited in the course of the admirable series of afternoon excursions which had been arranged by the local secretary of the section.

A full day was given to papers dealing with the Triassic rocks. Mr. H. T. Ferrar led off with a description of the features and activities of the desert regions of eastern and western Egypt, and he dealt more particularly with those which have a bearing on the origin of the British Trias. The Libyan Desert presents broad, featureless plains, with no very definite drainage system, and the veneer of waste is protected from removal by wind by layers of pebbles. The Etbai, on the other hand, displays bare hillsides free from débris, aggrading wadis, no sand dunes, and an integrated drainage system.

The origin of the Trias about Leicester was very ably discussed by $\mathrm{Mr}$. T. O. Bosworth. He showed that the Charnian rocks beneath the Keuper were fresh right up to the surface, and when the marl had been denuded, the igneous rocks of Mount Sorrel, Croft, Scapcote, Groby, \&c., were smoothed, fretted, and carved by wind action. The beds themselves dip in the direction of the slope of the underlying rocks, and catenary bedding is seen at Croft and Groby. At the base of the marls, too, there are breccias with chemically unaltered stones, and these he considered to be desert screes. Such evidence of subaqueous deposition as there is points to the existence of occasional streams and salt pools rather than the deep waters of one great Keuper lake.

Messrs. Keay and Gimson discussed the relation of the Keuper marls to the pre-Cambrian rocks at Bardon Hill. They showed that the Keuper fills in joints of the preCambrian rocks to a height of 880 feet, which is the greatest altitude yet reached in Britain for any rocks of the Triassic system.

Dr. Cullis, in dealing with the mineralogical constitution of the Keuper marls in the west of England, announced the discovery of minute crystals of dolomite, which he contended were precipitated from the waters of an inland sea. In the discussion which followed, $\mathrm{Mr}$. Lomas showed that dolomite was absent from the Keuper marls of the north of England, and their occurrence in the sands now being laid down by the River Mersey showed that other modes of origin are possible. The exact manner in which limestones become dolomitised and crystals of dolomite are produced in sands is still a matter of great uncertainty, and no satisfactory explanation has yet been offered.

Messrs. Bolton and Waterfall communicated a Daper on the occurrence of boulders of strontia in the Upper
Triassic marls of Abbots Leigh, near Bristol. This remarkable deposit contains boulders of all sizes from a pea to 100 tons in weight; the yield is about 2000 tons per acre, and it has become the principal world's supply of this mineral.

The fifth report of the committee appointed to investigate the fauna and flora of the Trias was presented by the secretary. To this report Dr. A. Smith Woodward contributed an important paper on a mandible of Labyrinthodon leptognathus, Owen, recently obtained from the Keuper sandstone of Cubbington Heath, near Leamington. Its structure confirms the recent conclusions as to the complex nature of the mandibular ramus of Labyrinthodonts, and helps to connect these early amphibians with the Palæozoic Crossopterygian fishes.

Mr. H. C. Beasley has taken advantage of the great find of footprints at Storeton, in Cheshire, last year to re-describe some of the forms hitherto imperfectly known, and $\mathrm{Mr}$. Lomas gave a detailed account of a large slab recently presented to the Liverpool University. This slab gives a track containing fifteen impressions made by the same individual, and the markings are so perfect that the minutest detail of the skin, claws, and movements of the animal which made them, can be observed. It is suggested that Cheirotherium walked erect, and only used the manus to steady itself when bending down to drink or feed. The rocks containing the footprints have been found to contain, besides quartz, felspars, zircon, tourmaline, anatase, rutile, kyanite, staurolite, chert, and numerous black grains not identified.

Mr. A. R. Horwood also contributed to the report an account of the plants and animal remains found in the Leicestershire Trias, and a bibliography of works referring to the flora and fauna of the Keuper of the district.

Mr. L. J. Wills gave an account of a very rich assemblage of fossils he recently obtained from the Lower Keuper of Bromsgrove, in Worcestershire.

Prof. Seeley, in describing the structure of the mandible of a South African Labyrinthodont, pointed out the great resemblance between the British Triassic fauna and that of the Karroo in South Africa.

A discussion on iron-ore supplies was opened by $\mathrm{Mr}$. Bennett Brough and Prof. Sjögren. Mr. Brough contended that as the production and consumption of iron per head of population is increasing year by year, and the world's production in 1905 attained the enormous total of $56,000,000$ tons, the outlook for the future is disquieting, though not necessarily depressing. The future of the home demand is likely to be affected by the development of the basic open-hearth process of steel making, which enables phosphoric ores to be utilised. The development of magnetic concentration and of the briquetting of pulverulent ores for furnace use will render possible greater utilisation of poorer ores, and the electric furnace will doubtless render it possible to use black sands and other titaniferous iron ores, which cannot be treated profitably in the blast furnace.

Prof. Sjögren took a more hopeful outlook in dealing with the Scandinavian iron ores. These are distributed in " ore-provinces" characterised by special geological structures. While the view that the iron-ore supply is unlimited is not well founded, the professor estimated that the total supply for the different provinces in Scandinavia is 1105 millions of tons of ore, equivalent to $5^{82}$ millions of tons of pig iron. Of these, 60 millions contain a low percentage of phosphorus and are suitable for reduction by the Bessemer process, 545 millions are richer in phosphorus and can be worked by the basic-hearth process, and 500 millions are lean ores only profitable to smelt after magnetic concentration.

Continuing the dicussion, Prof. Lapworth congratulated the association upon the importance of the rommunications. He referred to the great changes in the position of the centre of gravity of the iron industry. Years ago the native forests served for the working of the ores when the Weald was the great centre of output. When coal came to be used, the coalfields berame the great centres, and in later davs the ores of the Lias and Oolites had come to the front, and probably for some time they would be the chief British sources of supply.

Mr. G. W. Lamplugh said that an important aspect of

No. I975, voL. 76] 
the question was one of cost, and as the first-class ores became exhausted and prices rose, the second-class ores would prove remunerative.

Colonel Parrett took an optimistic view, and referred to the vast quantities of rich ore in Australia and the Transvaal.

The president, in closing the discussion, looked forward to Australia, with its vast coalfields and easy transport, becoming the great centre of iron production.

Mr. W. G. Fearnsides, in describing the pisolitic iron ores of North Wales, showed that they were not, as formerly supposed, cilaracteristic of certain geological horizons.

A paper by Prof. J. Joly, on the distribution of radium in the rocks of the Simplon Tunnel, raised many question of great interest. From the examination of thirty-six typical samples taken from various points in the tunnel, he showed them to contain varying amounts of radium, and, taken together, they were sufficient to disturb any forecast of the temperature which under normal conditions would be encountered at the level of the tunnel. presence of radium in the sediments, in hitherto un suspected quantities, raises the question whether its presence may not be a factor in the events attending mountain building. The shifting of radium and its parent elements by denudation must be regarded as a convection of thermal energy, and result in the shifting of areas of high temperature and crust-weakness from age to age as the site of sedimentary accumulation changes.

The chief papers dealing with palæontology were by Mr. F. Raw, on the trilobite fauna of the Shineton shales and on the development of Olenus salteri; the palæontology of the North Derbyshire coalfield, by Mr. A. R. Horwood, and reports from various research committees.

The Carboniferous Zones Committee, after several years of useful work, presented its final report, but the work which has been carried on with so much vigour and success by Dr. Wheelton Hind and others, will be continued by another committee of which Dr. A. Vaughan is secretary.

The committee appointed to investigate the fossiliferous drift deposits at Kirmington and at various localities in the East Riding of Yorkshire has devoted its energies to a careful examination of the mammaliferous gravels at Bielsbeck, in the Vale of York. The deposits occupy a depression in the Keuper marls, and have accumulated in a boggy hollow on an old land surface. None of the material excavated can be assigned to the direct agency of ice, and there is no evidence available which will definitely fix its age relatively to the Glacial period.

A new section of glacial gravels in Holderness was described by Messrs. Sheppard and Stather. They are considered by the authors to represent part of the terminal moraine of the North Sea ice sheet.

The pre-Devonian beds of the Mendip Hills were reported on by a committee appointed to examine their fossil contents and their relations to a peculiar coarse, ashy conglomerate found in the neighbourhood.

Mr. Lomas described the occurrence of a remarkable bed of peat found during excavations in the Union Dock, Liverpool. The chief interest of the deposit lies in the fact that the peat is composed of marine plants encrusted with polyzoa, hydrozoa, serpulæ, and other marine organisms.

Mr. A. R. Horwood read a paper on a hitherto unnoticed section of the Amaltheus spinatus zone in the Middle Lias at Billesdon Coplow, Leicestershire, and some notes on the ancient volcanoes of Basutoland were sent by the Rev. S. S. Dornan.

A catalogue of destructive earthquakes was submitted by Prof. J. Milne. Taking only those which have done structural damage, he finds that between the years II50 and 1250 A.D. large earthquakes were very frequent, and another great increase commenced about the year 1650 , and is still in progress.

Prof. Frech in, a subsequent paper showed the part which earthquakes have played in mountain building.

Reports on the Anglesey rocks, bv Mr. E. Greenly, and on erratic blocks, by Prof. P. F. Kendall, completed the papers read before the section.

No. I975, vol. 76$]$

\section{ENGINEERING AT THE BRITISH} ASSOCIATION.

IN accordance with its usual custom, the section did not meet on the opening day until Ir.15 a.m., in order that members might have an opportunity of attending the presidential addres

The

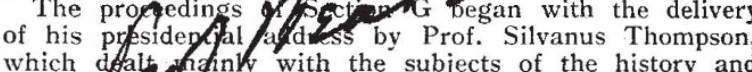
and with the subjects of the history and developherk of electric motive power, and the education and tralning engineers. After the vote of thanks to the president, Mr. Dugald Clerk read a paper on the present position of gas and petrol engines. The author pointed out that experience in the construction and design of large gas engines is gradually accumulating, but that the conditions of work in this country differ in one important respect from those on the Continent. Practically all the large Continental gas engines are operated with blastfurnace gas, while in this country producer gas has been almost exclusively used, and he was of opinion that until the problem of the bituminous fuel producer was solved, it would be difficult to continue to increase the dimensions of gas engines. Mr. Clerk himself has been working for some years now at the problem of reducing maximum pressures as well as temperatures, without reducing mean pressures, in order that the thickness of the cylinder castings, \&c., might be reduced, and that the weight of the engine itself might be made more reasonable for moderate powers; he has been experimenting with a 50 horse-power engine in order to obtain definite data as to the rates of cooling of the working fluid in the actual engine at different temperatures and pressures, and he showed a very interesting diagram illustrating his results, and a table of apparent specific heats of the working fluid at varying degrees of temperature which he had worked out from these experiments. This table showed conclusively a rapid increase of apparent specific heat with increase of temperature. From the values of the specific heat thus obtained, Mr. Clerk was able to obtain a curve of heat loss to the sides of the cylinder both for complete double strokes and for partial double strokes at the inner end of the stroke. The paper concluded with a brief discussion of some interesting points in connection with the petrol engine, and especially with the problem of the exhaust gases. The author showed by results of experiments on his own motor-car that by adjusting the carburetter he was able to reduce the percentage of $\mathrm{CO}$ in the exhaust gases very considerably.

In the afternoon the members of the section had an opportunity of visiting the works of Messrs. N. Corah and Sons, hosiery manufacturers, where they saw many examples of the most efficient and up-to-date machinery now used in the manufacture of hosiery. The works are extremely well planned, and reflect the greatest credit upon the proprietors, not only for the skill with which the machinery has been arranged and working costs kept down, but for the great attention paid to ventilation in the workrooms and to the comfort and general well-being of the employees.

Friday morning, with the exception of a short paper by Prof. B. Hopkinson and Mr. L. G. E. Morse on the gases exhausted from a petrol motor, was entirely devoted to a joint discussion with Section $\mathrm{B}$ on gaseous explosions with special reference to temperature. Prof. Hopkinson and Mr. Morse in their paper gave an account of experiments which had recently been carried out in the engineering laboratory of Cambridge University on a four-cylinder Daimler engine in order to determine the conditions under which carbon monoxide is formed in an internal-combustion motor, and the relation between the composition of the exhaust gases, the strength of the mixture, the power developed by the engine, and the thermal efficiency. These experiments showed that the curve obtained by plotting the thermal efficiency reckoned on the indicated horse-power to a base of petrol consumption had a sharply defined maximum near the point where the consumption was about $2 /$ ioth $\mathrm{lb}$. of petrol per 1000 revolutions, or at the point at which the petrol is just sufficient to be burnt by the available oxygen. The rapid increase in the per- 